\title{
Curbing adult student attrition: Evidence from a field experiment
}

\section{Citation}

Chande, Raj, Michael Luca, Michael Sanders, Xian\#Zhi Soon, Oana Borcan, Netta BarakCorren, Elizabeth Linos, Elspeth Kirkman, and Sean Robinson. "Curbing Adult Student Attrition: Evidence from a Field Experiment." Harvard Business School Working Paper, No. 15-065, February 2015.

\section{Permanent link}

http://nrs.harvard.edu/urn-3:HUL.InstRepos:14369096

\section{Terms of Use}

This article was downloaded from Harvard University's DASH repository, and is made available under the terms and conditions applicable to Open Access Policy Articles, as set forth at http:// nrs.harvard.edu/urn-3:HUL.InstRepos:dash.current.terms-of-use\#OAP

\section{Share Your Story}

The Harvard community has made this article openly available. Please share how this access benefits you. Submit a story.

Accessibility 

H A R V A R D
B U S I N E S S
S C H O O L

\section{Curbing Adult Student Attrition: Evidence from a Field Experiment}

$\begin{array}{ll}\text { Raj Chande } & \text { Michael Luca } \\ \text { Michael Sanders } & \text { Xian-Zhi Soon } \\ \text { Oana Borcan } & \text { Netta Barak-Corren } \\ \text { Elizabeth Linos } & \text { Elspeth Kirkman } \\ \text { Sean Robinson } & \end{array}$

\section{Working Paper}

15-065

February 1, 2015

Copyright (c) 2015 by Raj Chande, Michael Luca, Michael Sanders, Xian-Zhi Soon, Oana Borcan, Netta Barak-Corren, Elizabeth Linos, Elspeth Kirkman, and Sean Robinson

Working papers are in draft form. This working paper is distributed for purposes of comment and discussion only. It may not be reproduced without permission of the copyright holder. Copies of working papers are available from the author. 


\title{
Curbing adult student attrition: Evidence from a field experiment*
}

\author{
February 1, 2015 \\ Raj Chande†, Michael Luca‡, Michael Sanders§, Xian-Zhi Soon**, Oana Borcan††,

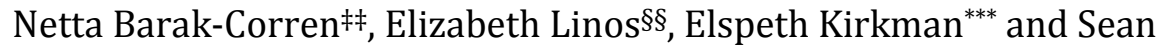 \\ Robinson****
}

\begin{abstract}
Roughly $20 \%$ of adults in the OECD lack basic numeracy and literacy skills. In the UK, many colleges offer fully government subsidized adult education programs to improve these skills. Constructing a unique dataset consisting of weekly attendance records for 1179 students, we find that approximately $25 \%$ of learners stop attending these programs in the first ten weeks and that average attendance rates deteriorate by $20 \%$ in that time. We implement a large-scale field experiment in which we send encouraging text messages to students. Our initial results show that these simple text messages reduce the proportion of students that stop attending by $36 \%$ and lead to a $7 \%$ increase in average attendance relative to the control group. The effects on attendance rates persist through the three weeks of available data following the initial intervention.
\end{abstract}

Keywords: Behavioral Economics, Field Experiment, Education, Adult Education

\footnotetext{
* This research is funded by the UK government department for Business, Innovation and Skills, through a grant to the Behavioural Insights Research Centre for Adult Skills and Knowledge. We are grateful to Angela Rooney-Tchetchnev, Sharon Starkey, Lucy Pates, Sandra Riding, Kully Sandhu, Steve Middleton and Verity Hancock at Leicester College and Claire King, Damien Steel, Angela Foulkes, Rhys Crombie and Lisa O'Loughlin at Manchester College for their assistance in conducting this experiment. Thanks to Patrick Rooney for excellent research assistance and to Owain Service for comments on an earlier draft.

† Behavioural Insights Team, ASK, and University of Bristol

\# Harvard Business School

$\S$ Behavioural Insights Team and Harvard Kennedy School of Government

** ASK, Behavioural Insights Team

${ }^{\dagger}$ ASK, Behavioural Insights Team, and University of Gothenburg

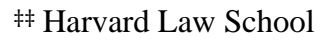

$\S \S$ ASK, Behavioural Insights Team, and Harvard Kennedy School of Government

${ }^{* * *}$ ASK, Behavioural Insights Team

**** ASK, Behavioural Insights Team
} 


\section{Introduction}

According to a recent assessment, roughly $16 \%$ and 19\% of OECD adults have low proficiency in literacy ${ }^{10}$ and numeracy, ${ }^{11}$ with low proficiency being defined as failing to achieve the level expected of a 16 year-old. These groups suffer inferior health and labor market outcomes and demonstrate lower levels of civic engagement and trust in society (OECD, 2013 and BIS, 2014). Many community colleges offer subsidized literacy and numeracy programs aimed at this population; similarly, the UK government spends around one billion pounds per year on such courses, undertaken by approximately one million adults each year at no charge to the learner (BIS Skills Funding Statement, 2014).

While many adults enroll in these skills programs, there are significant barriers to attendance and completion. Many adult learners have never entered higher education, and have been out of the educational system altogether for years before enrolling. Moreover, enrollees in adult skills courses have often performed poorly during their compulsory education and therefore have fragile confidence and motivation to improve their skills (Gorard et al, 2006; Armstrong et al, 2006). These factors can create psychological barriers to attending.

Adult learners can also face high opportunity costs to attending. Relative to younger students, adult learners are more likely to be working and have children. While at home or work, the benefits of numeracy and literacy may seem less top of mind than the immediate challenge of attendance.

This paper presents evidence from a large-scale field experiment designed to improve attendance rates by texting motivational messages and organizational reminders to students, with messages drawing on insights from behavioral economics. We find that the intervention has a large effect on attendance rates, and that this effect persists for the remainder of our sample period (three consecutive weeks of messaging).

To implement this experiment, we partnered with two further education colleges in England, consisting of 1179 adult learners. Both schools offer fully subsidized numeracy and literacy courses for adult learners. We begin by analyzing attendance patterns of the control group to gain insight into the dynamics of attendance.

We find that for the first three weeks, attendance is relatively low but steady at roughly $70 \%$. Attendance then begins to decline for several consecutive weeks and drops down to roughly $57 \%$ by the ninth week. Within an adult

\footnotetext{
${ }^{10}$ Literacy is defined as "the ability to understand and use information from written texts in a variety of contexts to achieve goals and develop knowledge and potential."

${ }^{11}$ Numeracy is defined as "the ability to use, apply, interpret, and communicate mathematical information and ideas."
} 
learner, there is significant persistence in changes in attendance behavior suggesting scope for changing the habits of learners.

Working with the colleges, we then implement a field experiment in which we send text messages to students each week beginning in the mid-term break (the sixth week). We chose this as a starting date for two reasons. First, this allowed us to observe baseline attendance rates for each student. Second, a growing body of literature within behavioral economics suggests the importance of temporal breaks in habit formation. Looking at the likelihood of completing a weekly task, Taubinsky (2013) investigates the economics of habit formation, and shows that forcing participants to skip a week reduces the likelihood that they will return to the task the following week (even though the break was planned). Dai et al (2014) document the idea of a fresh start effect, showing that temporal landmarks are a good opportunity to create new habits as well. Hence, a weeklong break is a natural point at which attendance might drop and where simple nudges may be effective.

Our intervention messages leverage and test insights based in behavioral economics. First, they make class more salient when students are home, hence shifting their attention. Second, they encourage students to engage with their classmates on Facebook, which can increase a sense of belonging. Third, they provide encouraging messages - such as "keep up the hard work" - that can serve as nonpecuniary incentives.

Should we expect this intervention to influence attendance behavior? On the one hand, this is a very mild intervention, merely shifting the attention of students while providing no financial incentives and no new information. If adult students are not attending because they are constrained by other responsibilities, then we would not expect to see an effect. On the other hand, there is growing evidence of the role of psychology and behavioral economics in decisions such as whether to matriculate in college (Bettinger et al 2012, Pallais 2013, Castleman \& Page forthcoming). Carrell \& Sacerdote (2013) and Bettinger \& Baker (2011) show that once students are in school, coaching and mentoring can help to reduce drop-out rates. This suggests scope for leveraging behavioral economics in this context.

Empirically, we find that the proportion of students that stop attending is reduced by a third, with only $16 \%$ of the treatment group ceasing to attend classes compared to $25 \%$ of the control group. Average attendance is $7 \%$ higher in the treatment group (a difference of approximately 4\% points) and this effect shows no signs of decaying for three weeks after the intervention.

This paper contributes to the literature on the behavioral foundations of educational decisions - and more generally, on the implementation of behavioral field experiments. Our contribution to this literature is threefold. First, we shed light on the behavioral foundations of adult learning and the dynamics of student attendance. Second, our results provide evidence on the role of simple behaviorally informed interventions within a classroom context. At roughly $\$ 5$ 
per learner per year, this is a very cost-effective way of improving attendance rates. Third, one potential criticism of these types of behavioral interventions is that they may dull over time with repeated exposure (Alcott and Rogers 2014). The persistence of the effects in the 3 weeks after the start of the intervention provides initial evidence that repeated exposure to messages does not dull the effect in our context - at least in the short term.

The remainder of the paper is organized as follows: Section 2 reviews the empirical context. Section 3 details the experimental design and the intervention. Section 4 presents the results. Section 5 concludes.

\section{Empirical Setting}

Despite growing high school graduation and college attendance rates, improving basic literacy and numeracy skills remains an important policy issue at the lower part of the educational distribution. In the UK, a 1999 report found that approximately $20 \%$ of the British adult population "lacked the basic skills required to function in work and society," driven by low literacy and numeracy rates (DfEE, 1999). The government responded in 2001 with Skills for Life (SFL), a course of study for adult learners aimed at increasing the educational levels of the lowest-skilled and preparing them for better employment opportunities.

These courses led to an increase in self-esteem and self-perceived ability to learn among program participants (Metcalf et al. 2009). While initial research was inconclusive about the impact of skills-training on employment and earnings, subsequent studies have shown that students who complete basic courses are more likely to take higher-level classes, which in turn leads to improved labor market outcomes (Boe 1997; Bonjour and Smeaton 2003; Bynner et al 2001).

The UK government has now set a goal for $95 \%$ of the British population to achieve basic levels of skills by 2020 (HM Treasury, 2006). Further education colleges are the main providers of these courses in the UK, educating more than 950,000 learners in the academic year 2013/14 (BIS, 2014).12

While enrollment has been steady for the past five years, the proportion that goes on to "achieve" (pass the qualification) is low and declining. During this period, achievement has dropped from 67\% to below 60\% (Skills Funding Agency, 2015). A major reason for non-achievement is that learners drop out of their programs (Newman-Ford et al 2008). Informal discussions with prospective trial partner colleges suggested that learners drop out steadily throughout the year, with increased attrition observed after breaks such as those for Christmas, Easter, or mid-term breaks (conversations with program administrators at Leicester College, 7/18/2014; and Stoke on Trent, 7/22/2014).

12 Some of these learners will be the same people taking multiple courses; no data are available on how many people form this group of 950,000 enrollments per year. 
There are several possible factors contributing to low attendance. In a 2000 Basic Skills Agency survey, 51\% of adults felt that being too busy and not having enough time was the main barrier to improving their basic skills. Other main reasons given were the inability to get time off work for learning (17\%) and financial constraints (13\%) (see also Tomoana \& Heinrich, 2004; Kambouri \& Francis, 1994; Barton et al., 2006; Comings et al. 2009). Within the education literature, Davies (2001) notes that learners' attitudes towards their educational experience are more predictive of success than their background. Moreover, motivation to learn is a strong predictor of enrollment, persistence, and success in basic skills courses (e.g., Gorard et al., 2004; Webb, 2006; MacLeod \& Straw, 2010).

\section{Experiment Design}

\subsection{Partner Colleges and Sample}

Our experiment took place in 2 further education colleges in England; Leicester College and Manchester College. ${ }^{13}$ Both colleges provide courses for younger learners in compulsory and vocational education as well as voluntary adult learners. Annually, Leicester College has approximately 2500 adult learners taking literacy and numeracy courses and Manchester College has approximately 1500 of these learners. In both colleges, adults are approximately $25 \%$ of the learner population. Both colleges are arranged across multiple campuses (purposely built to accommodate large numbers of learners) and smaller community venues (often local community centers that host part-time courses and facilitate the reach out to adult learners). Courses are either taught on an "Evening" (structured curriculum with examinations usually taken the end of the year) or "Part-Time" (less structured curriculum, examinations taken more irregularly) basis. Table 1 documents the number of courses taught across the two schools.

In our field experiment, learners were 19 or older and enrolled in basic math and/or English programs, which run on approximately the same academic calendar as schools and universities - September through June. There are 3 semesters: Autumn, Spring, and Summer. Each semester has a one-week break in the middle. Learners complete no assessments apart from an examination at the end of the course, so there are no attainment data available. Learners continue to enroll throughout the year, but anyone who enrolled after the date of the first text (in October, the mid-term break) was excluded from the study.

\footnotetext{
${ }^{13}$ A third college participated in the trial and delivered the intervention. However, at the time of writing, it has not been possible to match records of the classes who were treated with subsequent attendance data (due to the way this third college stores their data means).
} 
The courses in our sample vary in difficulty and in topic, although we generally do not have enough power to detect heterogeneous treatment effects across courses. Learners might be enrolled in math, English, or math and English courses. Variances in difficulty in these courses are referred to as "levels." Most learners in either subject will be aspiring to obtain "Level 2," the equivalent of a grade $\mathrm{C}$ or above in GCSE (the high-stakes standardized examination taken by 16 year-olds in England; similar to SATs). Learners will often take Entry Level or Level 1 qualifications before entering Level 2 qualifications, though teaching for adjacent levels are often delivered together. ${ }^{14}$

Most courses will be taught on campus in groups of approximately 10 at the same time each week. A substantial minority of learners who cannot attend a class at the same time each week will instead enroll in "independent learning," where they can "drop in" at one of the community venues to learn when they have spare time, receiving help from on-site tutors. Such classes are often much larger, as learners are unlikely to all be there at the same time.

Informal discussions with partner colleges indicated that observable and unobservable characteristics of new enrollers are likely to systematically vary across different types of courses, as would subsequent attendance rates and achievement. College administrators reported lower enrollment for math classes in general, possibly because math is more abstract, more challenging, and induces greater anxiety of failure than English among learners. Administrators also speculated that attrition rates might vary depending on method of instruction (evening vs part-time). Hence, randomization was stratified along these class characteristics where possible.

\subsection{Randomization}

The trial had two conditions (see "Interventions," below). Half of the classes were randomized to receive the treatment and half of the classes were randomized to the control arm. To reduce the extent of within-class spillover (which would downward bias any possible results), randomization was conducted at the class-level, such that either everyone in a class was treated, or nobody was. As explained above, randomization was stratified by college, class content (Math/English), campus, and method of instruction (evening or parttime). Only learners that had enrolled before the first texts had been sent were included.

The structure of our sample posed challenges for randomization. Specifically, because participants could enroll in multiple courses, participants could be part of two classes, one of which was assigned to the treatment group, and one to the control group. If text messages are effective at encouraging participants to attend the class they refer to, they may also be effective at

\footnotetext{
${ }^{14} \mathrm{~A}$ table and explanation of qualifications in the UK can be found in Appendix A.
} 
encouraging participants to attend others, and so there is a risk of within-subject spillovers. This is particularly likely, as the language of the text messages is not tailored to specific classes. In our analysis, we consider these effects by analyzing an individual as treated first if their class is treated, and second if any of their classes are treated.

Because there were class-level Facebook groups, contamination effects were reduced, as were potential feelings of exclusion from a relevant learning resource by class-level randomization. Informal conversations with college informants revealed that inter-class communication is highly unlikely in the adult learning setting, and thus was less of a concern than initially thought.

\subsection{Outcome Measures}

Our primary outcome measures are weekly class attendance by students and the proportion of students that stop attending, where a participant is said to have dropped out if they are absent for three weeks, the entire period after our intervention that we have data. ${ }^{15}$ Our partner colleges (and more generally, further education colleges) do not conduct exams or grade assignments submitted by adult learners, and so no grades are available at the end of the first semester.

\subsection{Interventions}

The experiment consists of sending multiple messages and prompts via text. Each treated learner received several text messages throughout the duration of the course (which goes beyond the first semester, which is the data that is currently available and analyzed in this paper), sent on behalf of the college. Relative to earlier interventions, these messages require very little investment on the part of the college as they seek to influence behavior without changing the level of assistance, incentive, or information that students have.

The messages target three types of barriers that were hypothesized to prevent learners from completing their courses: lack of social support networks, lack of positive feedback and encouragement, and planning problems. The program of messages aimed to increase persistence by prompting learners to organize themselves for their classes in the week ahead, and by nurturing their motivation for learning. Examples of texts that attempted to foster these beliefs and that prompted advanced planning of attending classes are detailed below. A full catalogue of all messages sent can be found in the Appendix.

\footnotetext{
${ }^{15}$ Attendance records are not habitually stored digitally at either of our partner colleges. To obtain the data for this study, a temp was sent to digitize paper attendance records.
} 
Before the experiment, all students were notified they may or may not receive text messages designed to support their learning. ${ }^{16}$ Control learners did not receive any further message during the duration of the trial. Treatment learners were texted motivational messages and planning prompts with a link to a Facebook page specifically created for their class (which they already knew about). Mobile phone numbers were acquired from college administrative records and messages were sent using a bulk SMS system. The first text messages were sent during the midterm break. Three messages were sent during this one-week period, after which point messages were sent every Sunday evening at $7 \mathrm{pm} .{ }^{17}$ The software used enabled texts to be customized to include the learner's first name and the class in which they were enrolled (with a corresponding Facebook link), but other than those details, all learners received the same messages. Therefore, minimal administrative time was required to deliver the intervention. Were the texts to be delivered for an entire year, the intervention would cost less than $\$ 5$ per learner, including administrator time.

\subsection{Data Description}

At the end of the semester, our partner colleges provided us with weekly attendance records for each (deidentified) student, which were merged with treatment assignments. Each dataset contains participants who were randomly assigned but never attended any classes prior to the intervention, and participants who joined the school after random assignment. These participants are excluded from analysis without substantially impacting our findings. Each observation is an enrollment in a class, so an individual may appear in the dataset multiple times if they are enrolled in multiple courses. A substantial number of new learners will continue to enroll throughout the year, but anyone who did so after the first texts were sent in the half-term break were excluded from the study.

This produces two datasets - one for each of the colleges in our study, which are then pooled. The dependent variables are a learner's weekly attendance, measured in percentages as the number of times they attended out of the number of weekly meetings they had in their course, and a measure of whether they drop out, based on having zero attendances in the three weeks after our intervention commenced (the period for which we have data).

These data contain participants' weekly attendance before and after the introduction of the treatment, as well as an identifier that allows us to observe whether a participant/class observation is subject to treatment, and to track

\footnotetext{
${ }^{16}$ In accordance with standard IRB procedures, learners in both Treatment and Control groups were notified a research project was being conducted at the college and that they had the right to either opt-out of the intervention or their data being used in subsequent analyses.

${ }^{17}$ Learners were able to opt out from further texts at any time. If they replied to a text, they would have received an automated response telling them to text "STOP" if they wanted to receive no further messages.
} 
participants across multiple classes. For participants in multiple classes, we derive a variable set to 1 if they are treated in any of their classes, and 0 if they are treated in none of the classes that they take.

A summary of these data, as well as balance checks for past attendance, can be found in Table 2 . There is no statistically significant difference between attendance prior to the experiment between the treatment and control groups in the pooled sample $(\mathrm{p}=0.79)$. This finding is common to data from Leicester and Manchester colleges $(p=0.84$ and $p=0.74$, respectively). This suggests that randomization was successful.

\section{Results}

\subsection{Dynamics of Class Attendance}

Figure 1 shows the pattern of attendance in the control group for the period covered by our data, with the vertical red line denoting the beginning of our experiment and the half term break. Average attendance starts at $70 \%$; informal discussions with colleges indicated this is not uncommon as learners will either be "course shopping" or may have already been discouraged. During the 10 -week span of the experiment, there is a $20 \%$ fall in attendance among the control group that becomes steeper after the half term point.

\section{2 The Impact of Messages on Attendance}

Table 3 presents the main results. Because treatment was assigned at the class level, some students received messages for one class but not the other. Clearly, these messages might also influence their behavior in both classes. The variable "Treated (this class)" defines treatment as whether the student received a message for that particular class whereas "Treated (any class)" defines treatment as whether the student received a message for any class.

Across the specifications, the treatment messages have a positive and significant effect on attendance levels, ranging form three to five percentage points (roughly a 7\% increase). This is robust to controlling for lagged attendance, student fixed effects, and time controls.

\subsection{Heterogeneous Treatment Effects}

Table 4 documents heterogeneous treatment effects. Column 1 shows that the treatment effect is smaller for individuals with higher pre-treatment attendance rate, which is the group that is most likely to drop out. Column 2 shows that the treatment effect is smaller for students who are taking multiple classes, perhaps because they are already more motivated. Column 3 includes a "dosage" variable indicating the proportion of a student's classes in which they 
are treated, to determine whether receiving more messages makes a participant more (or less) likely to attend class, and shows a positive but insignificant impact of being treated multiple times.

Table 5 shows the effect broken out by week. Although our data do not contain truly "long term" effects, it is possible to determine for the period covered by our data whether or not participants continue responding to treatment, or whether the effects are short lived. Looking at Figure 3 and at Table 5, the effects directionally persist but are noisy and inconclusive.

\subsection{The Impact of Messages on Dropout Decisions}

Thus far, we have focused primarily on overall attendance rates. In this section, we investigate drop out decisions as well as decisions to always attend. Results are presented in Table 6.

Columns 1 and 2 regress a binary dropout variable on treatment as well as control variables. Dropout is defined as one for any student who attended none of the last three classes of the semester. There is a significant and substantial drop in dropout rates among treated participants, among whom dropout rates fall from $25 \%$ to $16 \%$.

Columns 3 and 4 regress an indicator for whether the participant attends all classes after the intervention (three classes remain after the break). Oddnumbered columns consider treatment-in-class and even-numbered columns consider treatment-in-any-class. There is a small, insignificant of treatment on full attendance rate.

Overall, these findings are consistent with the subgroup analyses conducted above, which shows that people with the lowest attendance (those most at risk of dropping out), are most beneficially affected by our treatment. This also suggests that results are being driven by decisions of whether or not to drop out, as opposed to decisions about whether to skip a single class.

\subsection{Robustness}

As has been noted, the presence of participants in multiple clusters offers a potential source of bias to our experiment. As a robustness check, we therefore conduct the same analysis as in Table 3, Column 2 for a reduced sample of only those participants who take only one class (X Control participants and Y treated participants), or for those who take more than one class. The results of this analysis may be found in table 7. As noted previously, our study is not powered to detect effects in these subsamples individually. However, the point estimates are in the same range as those reported previously. 


\section{Discussion}

This paper has reported the results of a field experiment carried out on adult learners in two UK colleges. In contrast with earlier behaviorally informed interventions, which typically required extra guidance counselors or assistance in filling out forms, our intervention influenced behavior without providing any new information, assistance, or financial incentives. In this sense, we were purely leveraging insights about student attention and decision-making, imposing virtually no additional cost on the organization that might implement this type of intervention.

We find that these text messages have a positive and significant effect on attendance of individual classes and, perhaps more importantly, that these effects are particularly concentrated on participants who are at high risk of nonattendance, reducing the proportion of learners who stop attending by approximately one third. We are unable to detect an effect on the probability of attending every class after our intervention. The returns on investment for this low-cost intervention are high enough to justify its use. 


\section{References}

Allcott, Hunt, and Todd Rogers (2014). "The short-run and long-run effects of behavioral interventions: Experimental evidence from energy conservation," The American Economic Review, Vol. 104, No. 10.

Armstrong, D., Barton, D., Hodge, R., Ivanic, R \& Tusting, K. (2006). "Relating adult lives and learning: participation and engagement in different settings," London: National Research and Development Centre for Adult Literacy and Numeracy.

Barton, D., Appleby, Y., Hodge, R., Tusting, K., \& Ivanic, R. (2006). “Relating adults' lives and learning: Participation and engagement in different settings," London: National Research and Development Centre for Adult Literacy and Numeracy.

Bettinger, Eric, and Rachel Baker, 2011. "The effects of student coaching in college: An evaluation of a randomized experiment in student mentoring," NBER Working Paper No. w16881.

Bettinger, Eric P., et al. "The Role of Application Assistance and Information in College Decisions: Results from the H\&R Block Fafsa Experiment*." The Quarterly Journal of Economics 127.3 (2012): 1205-1242.

BIS (2014). FE Trends. London: Department for Business, Innovation \& Skills.

BIS (2015). Skills Funding Statement 2013-16. London: Department for Business, Innovation \& Skills

BIS (2013) The International Survey of Adult Skills 2012: Adult literacy, numeracy and problem solving skills in England. London: Department for Business, Innovation \& Skills

Boe R. "A Two-Year Follow-Up of Federal Offenders who Participated in the Adult Basic Education (ABE) Program." Ottawa: Correctional Service of Canada Research Report no R-60, 1997.

Bonjour D and Smeaton D. "The Impact of Adult Basic Skills Pathfinder Extension Activities: stage 2 of the evaluation." London: Department for Education and Skills Research Report no 238, 2003.

Bynner J, McIntosh S, Vignoles A, Dearden L, Reed H and Van Reenen J. "Improving Adult Basic Skills: Benefits to the Individual and to Society." DfEE Research Centre Wider Benefits of Learning, Report no 251, 2001.

Carrell, Scott E., and Bruce Sacerdote, 2013. "Late Interventions Matter Too: The Case of College Coaching New Hampshire," NBER Working Paper No. w19031.

Castleman, Benjamin, and Lindsay Page, 2015. "Summer Nudging: Can Personalized Text Messages and Peer Mentor Outreach Increase College Going 
Among Low-Income High School Graduates?" Journal of Economic Behavior and Organization, forthcoming.

Comings, J., Parrella, A., \& Soricone, L. "Persistence among adult basic education students in pre-GED classes (NCSALL Reports No.12)". Cambridge, MA: National Center for the Study of Adult Learning and Literacy, 1999.

Dai, Hengchen, Katherine Milkman, and Jason Riis, 2014. "The Fresh Start Effect: Temporal Landmarks Motivate Aspirational Behavior," Management Science, Forthcoming.

Davies P. "Closing the achievement gap - colleges making a difference." Learning and Skills Development Agency, 2001.

Department for Education and Employment. A Fresh Start - improving literacy and numeracy. London: Department for Education and Skills. (Also known as The Moser Report), 1999.

Farrington, Camille A., et al. Teaching Adolescents to Become Learners: The Role of Noncognitive Factors in Shaping School Performance--A Critical Literature Review. Consortium on Chicago School Research. 1313 East 60th Street, Chicago, IL 60637, 2012.

Fisher, Mercedes and Derek Baird. "Online learning design that fosters student support, self-regulation, and retention." Campus-Wide Information Systems 22 (2), 2005.

Gollwitzer, Peter. "Implementation Intentions: Strong Effects of Simple Plans." American Psychologist 54 (7), 1999.

Gorard, S., Selwyn, N., \& Furlong, J. (2004). How do adults learn at home? Paper presented at the British Educational Research Association Annual Conference, University of Manchester, 16-18 September.

Gorard, S., Smith, E., May, H., Thomas, L., Adnett, N., \& Slack, K. (2006). Review of widening participation research: addressing the barriers to participation in higher education. Bristol: Higher Education Funding Council.

Horner, R., G. Sugai, and C. Anderson. "Examining the Evidence Base for SchoolWide Positive Behavior Support." Focus on Exceptional Children 42 (8), 2010.

Junco, Reynol. "The relationship between frequency of Facebook use, participation in Facebook activities, and student engagement." Computers and Education 58, 2011.

Kambouri, M., \& Francis, H. (1994). Time to leave? Progression and drop out in basic skills programmes. London: Adult Literacy and Basic Skills Unit. 
Keller, J. M. "The use of the ARCS model of motivation in teacher training. In K. Shaw and A. J. Trott (Eds.), Aspects of educational technology volume XVII: Staff development and career updating." London: Kogan Page, 1984.

Keller, J. M. Motivational design of instruction. In C. M. Reigeluth (Ed.), Instructional-design theories and models: An overview of their current status. Hillsdale, NJ: Lawrence Erlbaum Associates, 1983.

Leitch, Lord Sandy. "Prosperity for all in the global economy - world class skills." London: HM Treasury and Leitch Review of Skills. (Also known as The Leitch Report), 2006.

Litster, J. (2007). Motivating Skills for Life learners to persist, progress and achieve. Literature Review. Final report to the Quality Improvement Agency. Coventry: QIA.

Martin, Andrew. "Enhancing student motivation and engagement: The effects of a multi-dimensional intervention." Contemporary Educational Psychology 33 (2), 2008.

Martin, Andrew. "Exploring the effects of a youth enrichment program on academic motivation and engagement." Social Psychology of Education 8, 2005.

Martinez, Paul. "Improving student retention and achievement: What do we know and what do we need to find out?" Learning and Skills Development Agency, 2001.

Macleod, S., \& Straw, S. (2010). Adult Basic Skills. Reading: CfBT Education Trust.

Melrose, Karen. "Encouraging Participation and Persistence in Adult Literacy and Numeracy Education: A Review." Behavioural Insights Research Centre for English and Maths (BIRCEM), 2014.

Metcalf, Hilary, Pamela Meadows, Heather Rolfe, Amar Dhudwar, Nick Coleman, Jo Wapshott, and Hannah Carpenter. "Evaluation of the Impact of Skills for Life Learning: Longitudinal Survey of Adult Learners on College-based Literacy and Numeracy Courses, final Report." National Institute of Economic and Social Research with BMRB Social Research, 2009.

Milkman, K., J. Beshears, J. Choi, D. Laibson, and B. Madrian. "Using implementation intentions prompts to enhance influenza vaccination rates." Proceedings of the National Academy of Sciences, 2011.

Nagaoka, J., C. Farrington, S. Ehrlich, D. Johnson, S. Dickson, R. Heath, and A. Mayo. "A Framework for Developing Young Adult Success in the 21 $1^{\text {st }}$ Century." University of Chicago Consortium on Chicago School Research, Working Paper, 2014. 
Nickerson, D., and T. Rodgers. "Do You Have a Voting Plan? : Implementation Intentions, Voter Turnout, and Organic Plan Making." Psychological Science, 21 (194), 2010.

Newman-Ford, L., Fitzgibbon, K., Lloyd, S., \& Thomas, S. (2008). A large-scale investigation into the relationship between attendance and attainment: a study using an innovative, electronic attendance monitoring system. Studies in Higher Education, 33(6), 699-717.

OECD (2013), OECD Skills Outlook 2013: First Results from the Survey of Adult Skills, OECD Publishing. http://dx.doi.org/10.1787/9789264204256-en

Pallais, Amanda. Small differences that matter: mistakes in applying to college. Journal of Labor Economics. Forthcoming.

Skills Funding Agency, 2015. Further education \& skills: Learner participation, outcomes and level of highest qualification held, Available at: https://www.gov.uk/government/statistics/learner-participation-outcomesand-level-of-highest-qualification-held.

Taubinsky, Dmitry, 2013. "From Intentions to Actions: A Model and Experimental Evidence of Inattentive Choice" working paper

Tomoana, J., \& Heinrich, J. (2004). Demand-side factors in adult foundation learning programmes: a review of the international literature completed for the Department of Labour. Wellington, New Zealand: Department of Labour.

Vorhaus, J., Litster, J., Frearson, M., Johnson, S. (2011). Review of research and evaluation on improving adult literacy and numeracy skills, research paper no. 61. London: Department for Business and Skills.

Ward, J., \& Edwards, J. (2002). Learning journeys: learners' voices; learners' views on progress and achievement in literacy and numeracy. London: Learning and Skills Development Agency.

Webb, S. (2006). Can ICT reduce social exclusion? The case of an adults' English language learning programme. British Educational Research Journal, 32(3), 481507.

Wlodkowski, R. J. "Enhancing adult motivation to learn, 3rd Edition." San Francisco, CA: Jossey-Bass, 2008.

Wlodkowski, R. J., \& Ginsberg, M. B. "Diversity and motivation: Culturally responsive teaching." San Francisco, CA: Jossey-Bass, 1995.

Yu, Angela, Stella Tian, Douglas Vogel, Ron Chi-Wai Kwok. "Can learning be virtually boosted? An investigation of online social networking impacts. Computers and Education 55, 2010. 
Tables

\begin{tabular}{llll}
\hline \multicolumn{4}{l}{ Table 1: Number of Courses by College } \\
\hline & Manchester & Leicester & Pooled \\
Part Time & 66 & 17 & 83 \\
Evening & 17 & 5 & 22 \\
All & 83 & 22 & 105 \\
Campuses & 11 & 5 & 16 \\
English & 47 & 10 & 57 \\
Math & 36 & 11 & 47
\end{tabular}

Table 2: Summary Statistics

\begin{tabular}{lccccc}
\hline & Leicester & Manchester & Full Sample & Control & Treatment \\
Observations & 915 & 717 & 1632 & 854 & 778 \\
Participants & 691 & 489 & 1179 & 505 & 674 \\
Classes & 87 & 65 & 152 & 78 & 74 \\
In Multiple Classes & $31.2 \%$ & $19.4 \%$ & $26.5 \%$ & & \\
Past Attendance & $67.5 \%$ & $64.0 \%$ & $66.0 \%$ & 65.82 & 66.20 \\
\hline
\end{tabular}




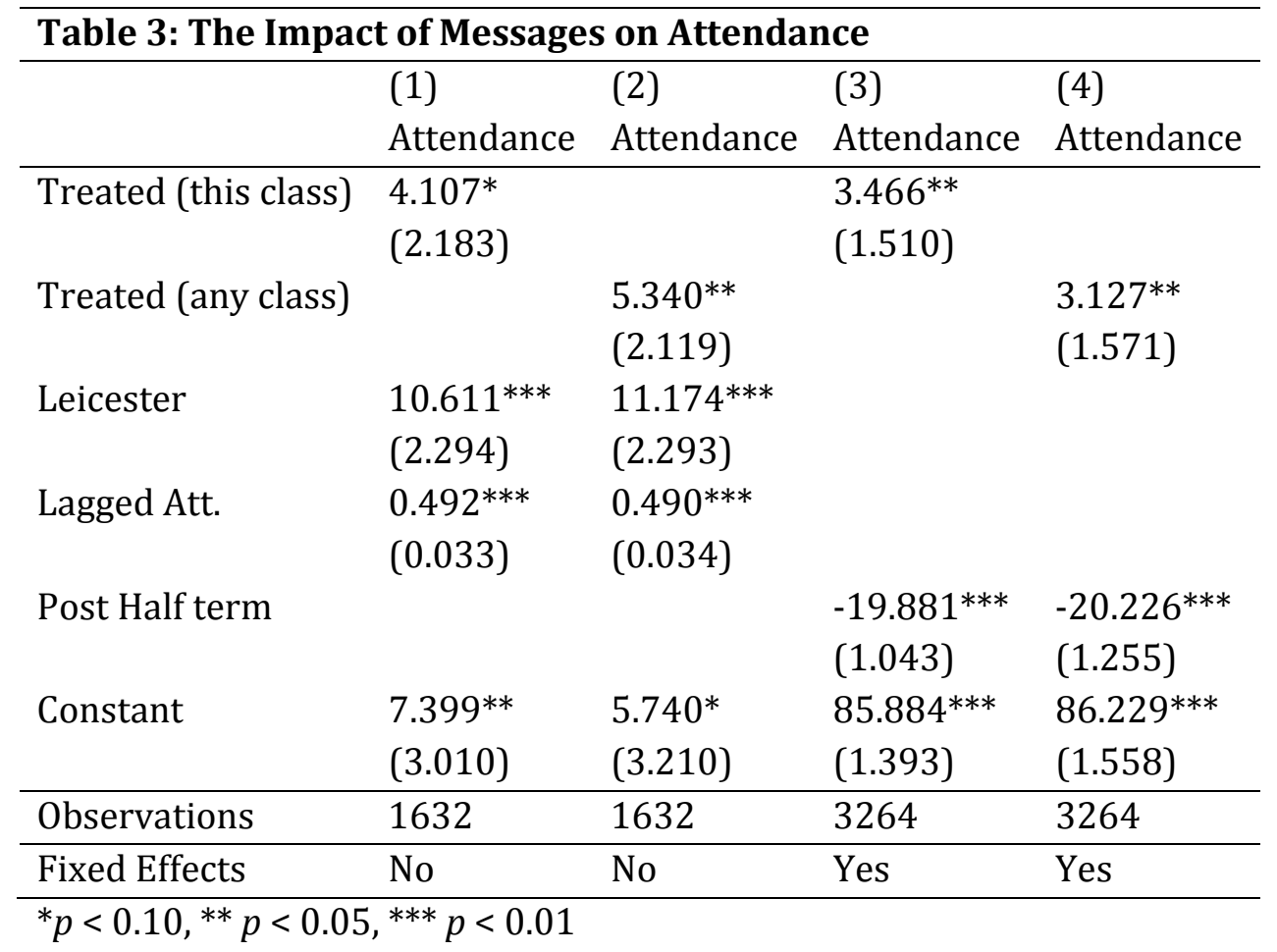




\section{Table 4: Heterogeneous Treatment Effects}

\begin{tabular}{|c|c|c|c|}
\hline & $\begin{array}{c}\text { (1) } \\
\text { Attendance }\end{array}$ & $\begin{array}{c}\text { (2) } \\
\text { Attendance }\end{array}$ & $\begin{array}{c}\text { (3) } \\
\text { Attendance }\end{array}$ \\
\hline Treated (any class) & $\begin{array}{c}7.861^{* * *} \\
(2.568)\end{array}$ & $\begin{array}{l}11.209^{*} \\
(6.173)\end{array}$ & \\
\hline Dosage of treatment & & & $\begin{array}{c}3.862 \\
(2.534)\end{array}$ \\
\hline Lagged Att. & $\begin{array}{l}0.505^{* * *} \\
(0.034)\end{array}$ & $\begin{array}{c}0.499 * * * \\
(0.034)\end{array}$ & $\begin{array}{c}0.492^{* * *} \\
(0.034)\end{array}$ \\
\hline $\begin{array}{l}\text { Lagged Att. x Treated (any } \\
\text { class) }\end{array}$ & $\begin{array}{l}-0.078+ \\
(0.043)\end{array}$ & & \\
\hline \# Courses & & $\begin{array}{l}6.489 * * \\
(3.236)\end{array}$ & \\
\hline \# Courses * Treated (any class) & & $\begin{array}{l}-6.102^{*} \\
(3.394)\end{array}$ & \\
\hline Leicester & $\begin{array}{c}13.865^{* * *} \\
(2.694)\end{array}$ & & $\begin{array}{c}10.599^{* * *} \\
(2.317)\end{array}$ \\
\hline Constant & $\begin{array}{c}3.040 \\
(3.411)\end{array}$ & $\begin{array}{c}4.131 \\
(6.092)\end{array}$ & $\begin{array}{l}7.495^{* *} \\
(3.227)\end{array}$ \\
\hline Observations & 1632 & 1632 & 1632 \\
\hline
\end{tabular}




\begin{tabular}{|c|c|c|}
\hline \multicolumn{3}{|c|}{ Table 5: Treatment Effect by Week } \\
\hline & $(1)$ & $(2)$ \\
\hline Treated (any class) & $\begin{array}{c}4.319 \\
(3.310)\end{array}$ & $\begin{array}{c}5.664 \\
(4.420)\end{array}$ \\
\hline Period 2 & $\begin{array}{c}-3.220 \\
(2.189)\end{array}$ & \\
\hline Period 3 & $\begin{array}{c}-2.712 \\
(2.800)\end{array}$ & \\
\hline Period $2 *$ Treated (any class) & $\begin{array}{c}3.700 \\
(3.349)\end{array}$ & \\
\hline Period $3 *$ Treated (any class) & $\begin{array}{c}-0.167 \\
(3.756)\end{array}$ & \\
\hline Leicester & $\begin{array}{l}9.748^{* *} \\
(2.963)\end{array}$ & $\begin{array}{l}9.748^{* *} \\
(2.963)\end{array}$ \\
\hline Lagged Att. & $\begin{array}{l}0.654^{* * *} \\
(0.040)\end{array}$ & $\begin{array}{l}0.654^{* * *} \\
(0.040)\end{array}$ \\
\hline Weeks & & $\begin{array}{c}-1.356 \\
(1.400)\end{array}$ \\
\hline Weeks $*$ Treated (any class) & & $\begin{array}{c}-0.084 \\
(1.877)\end{array}$ \\
\hline Constant & $\begin{array}{l}10.941^{*} \\
(4.453)\end{array}$ & $\begin{array}{l}11.676^{*} \\
(5.153)\end{array}$ \\
\hline Observations & 4896 & 4896 \\
\hline
\end{tabular}


Table 6: Effects of Treatment on Rate of Dropout and Full Attendance

\begin{tabular}{lllll}
\hline & $(1)$ & $(2)$ & $(3)$ & $(4)$ \\
DV: & Drop Out & Drop Out & Full Attendance & Full Attendance \\
\hline Treated (this class) & $-0.094^{* * *}$ & & 0.022 & \\
& $(0.028)$ & & $(0.030)$ & \\
Treated (any class) & & $-0.091^{* *}$ & & 0.018 \\
& & $(0.032)$ & & $(0.032)$ \\
Lagged Att. & $-0.006^{* * *}$ & $-0.006^{* * *}$ & $0.006^{* * *}$ & $0.006^{* * *}$ \\
& $(0.001)$ & $(0.001)$ & $(0.000)$ & $(0.000)$ \\
Leicester & $-0.148^{* * *}$ & $-0.157^{* * *}$ & 0.020 & 0.021 \\
& $(0.036)$ & $(0.036)$ & $(0.032)$ & $(0.033)$ \\
Constant & $0.757^{* * *}$ & $0.774^{* * *}$ & -0.032 & -0.033 \\
& $(0.057)$ & $(0.062)$ & $(0.028)$ & $(0.033)$ \\
\hline Observations & 1632 & 1632 & 1632 & 1632 \\
\hline${ }^{*} p<0.05,{ }^{* *} p<0.01,{ }^{* * *} p<0.001$ & &
\end{tabular}

Table 7: Robustness Check: Analysis by level of engagement

\begin{tabular}{lll}
\hline & $(1)$ & $(2)$ \\
& Attendance & Attendance \\
\hline Treated (any class) & 5.398 & 3.144 \\
& $(3.115)$ & $(2.398)$ \\
Lagged Att. & $0.495^{* * *}$ & $0.486^{* * *}$ \\
& $(0.045)$ & $(0.043)$ \\
Leicester & $13.045^{* * *}$ & $7.640^{* *}$ \\
& $(3.056)$ & $(2.619)$ \\
Constant & 3.549 & $11.794^{* *}$ \\
& $(3.937)$ & $(3.751)$ \\
\hline Observations & 862 & 770 \\
Number of classes taken & 1 & $>1$ \\
\hline${ }^{*} p<0.05,{ }^{* *} p<0.01,{ }^{* * *} p<0.001$ & \\
\hline
\end{tabular}




\section{Figures}

Figure 1: Examples of intervention texts by aim of text

\begin{tabular}{|l|l|}
\hline Aim of text & Example \\
\hline Advance Planning & $\begin{array}{l}\text { Hi (Name) it never hurts to plan ahead. Decide } \\
\text { when you will practice and mark next week's class } \\
\text { in your diary. (College Name) }\end{array}$ \\
\hline $\begin{array}{l}\text { Motivation (i) The course is } \\
\text { of value to learners }\end{array}$ & $\begin{array}{l}\text { (Name), how will what you've learnt help at home } \\
\text { or at work? Share this at your next (Class Name) } \\
\text { class. (College Name). }\end{array}$ \\
\hline $\begin{array}{l}\text { Motivation (ii) Learners are } \\
\text { making progress and can } \\
\text { succeed }\end{array}$ & $\begin{array}{l}\text { (Name), well done, you've reached the mid-term } \\
\text { break! Take time to practice what you've learnt \& } \\
\text { stay connected: (Class FB link) (College Name). }\end{array}$ \\
\hline $\begin{array}{l}\text { Motivation (iii) Ability } \\
\text { improves with effort }\end{array}$ & $\begin{array}{l}\text { (Name), did you know, learning improves your } \\
\text { brain power? Keep up the hard work and keep } \\
\text { improving. (College Name) }\end{array}$ \\
\hline $\begin{array}{l}\text { Motivation (iv) The class is } \\
\text { for people like the learners }\end{array}$ & $\begin{array}{l}\text { Hi (Name), at the college you're among friends. } \\
\text { Support each other through your studies. Post } \\
\text { your support on Facebook: (Class FB Link). } \\
\text { (College Name) }\end{array}$ \\
\hline
\end{tabular}


Figure 2: Baseline Attendance by Week

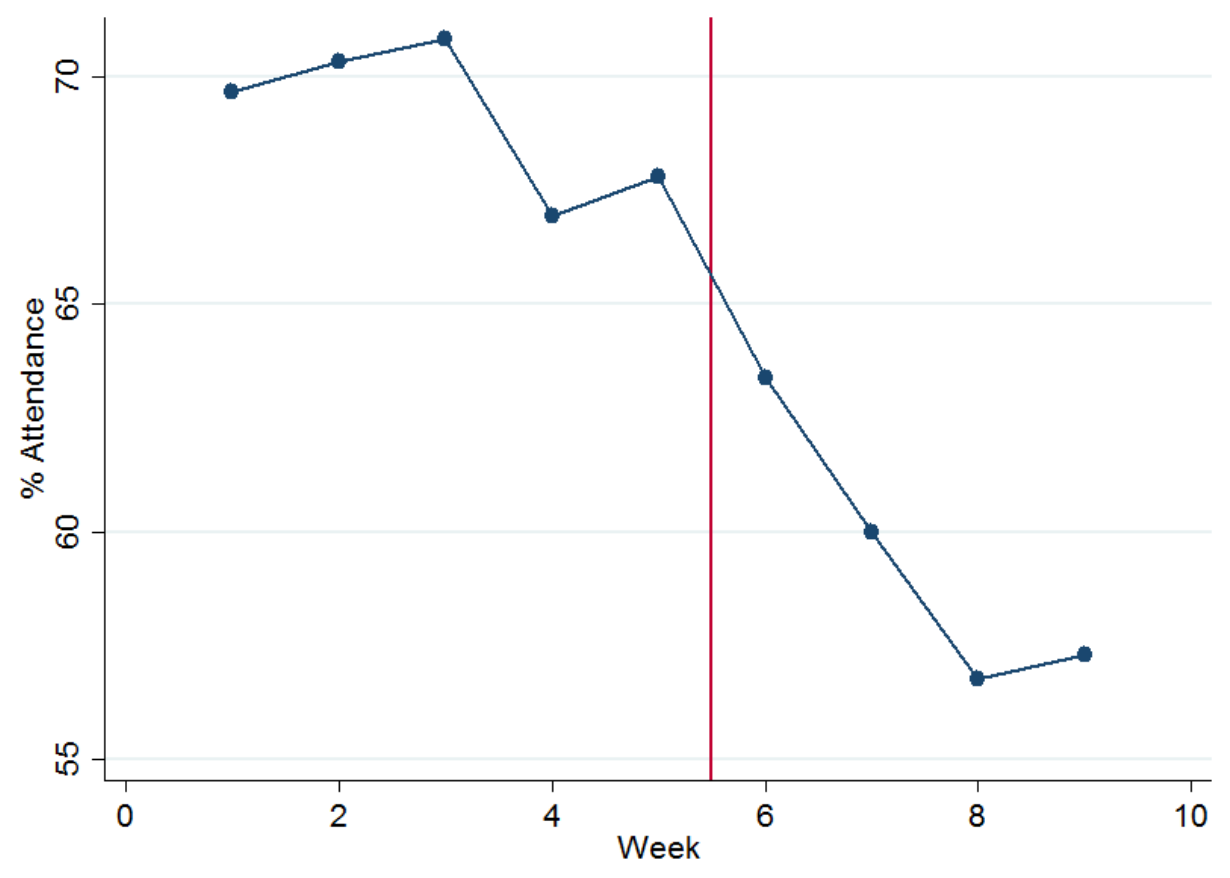

Figure 3: Impact of Intervention on Attendance

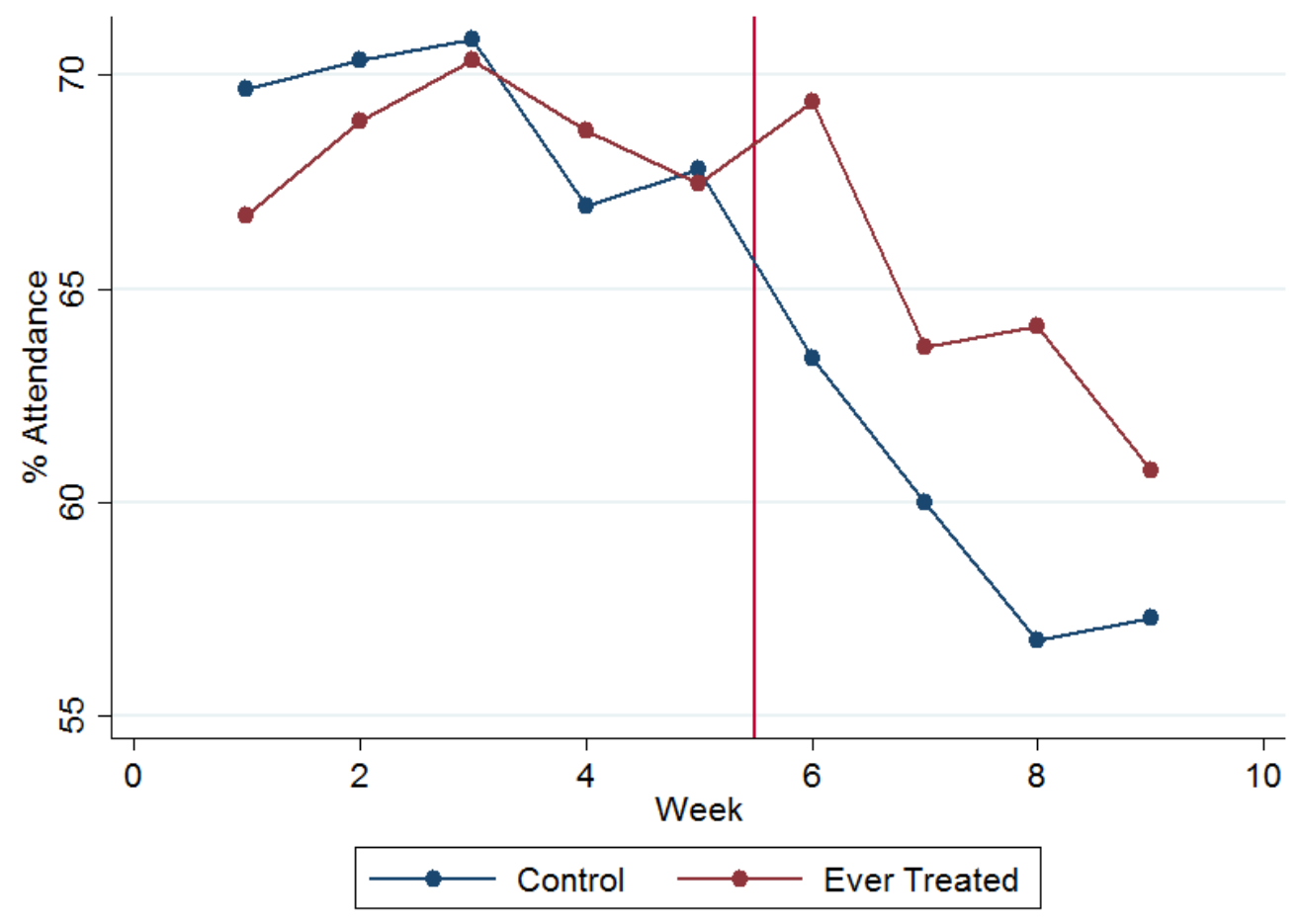




\section{Appendix}

\section{A: Full text schedule for study period by week}

\begin{tabular}{|l|l|}
\hline W & Full text \\
\hline 5 & $\begin{array}{l}\text { Hi. You may have heard about a research project taking place at your college. You can } \\
\text { read about it here: http://bit.ly/leic123. Thanks, College Name }\end{array}$ \\
\hline 6 & $\begin{array}{l}\text { Hi }\{\{\text { firstname\}\}, from tonight, we will send you texts to support your learning. Join your } \\
\text { class Facebook page: }\{\text { custom }\}\} \text {. College Name })\end{array}$ \\
\hline 6 & $\begin{array}{l}\{\{\text { firstname\}\}, well done, you've reached the mid-term break! Take time to practice what } \\
\text { you've learnt \& stay connected: }\{\text { custom1\}\}. College Name }\end{array}$ \\
\hline 6 & $\begin{array}{l}\{\{\text { firstname }\}, \text { hope you had a good break, we look forward to seeing you next } \\
\text { week. Remember to plan how you will get to your class. College Name }\end{array}$ \\
\hline 7 & $\begin{array}{l}\text { Hi }\{\{\text { firstname\}\}, think of } 3 \text { things you've enjoyed learning so far and share them on } \\
\text { Facebook with your classmates: }\{\text { custom1\}\}. College Name }\end{array}$ \\
\hline 8 & $\begin{array}{l}\text { Hi }\{\{\text { firstname\}\}, it never hurts to plan ahead. Decide when you will practice and mark } \\
\text { next week's class in your diary. College Name }\end{array}$ \\
\hline 9 & $\begin{array}{l}\{\{\text { firstname }\}, \text { did you know, learning improves your brain power? Keep up the hard } \\
\text { work and keep improving. College Name }\end{array}$ \\
\hline 10 & $\begin{array}{l}\{\{\text { firstname }\}\}, \text { how will what you've learnt help at home or at work? Share this at your } \\
\text { next }\{\{\text { custom2\}\} class. College Name. }\end{array}$ \\
\hline
\end{tabular}

